\title{
Copper and zinc interactions: morphophysiological responses in sweet potato plants (Ipomoea batatas L.)'
}

\author{
Cristina Copstein Cuchiara, Cristina Ferreira Larré \& José Antonio Peters
}

\author{
Department of Botany, Institute of Biology, Federal University of Pelotas, Capão do Leão, RS, 96160-000, Brazil. \\ cccuchiara@hotmail.com, cristina_larre@yahoo.com.br, japeters1@hotmail.com \\ 1 Parte da tese do primeiro autor no Programa de Pós-Graduação em Fisiologia Vegetal da Universidade Federal de Pelotas, \\ Rio Grande do Sul
}

Recebido em 11.IV.2016.

Aceito em 28.IV. 2017.

DOI: $10.21826 / 2446-8231201772113$

\begin{abstract}
The objective of this study was to evaluate the combined effects of copper $(\mathrm{Cu})$ and zinc $(\mathrm{Zn})$ on sweet potato plants based on morphological parameters, mineral profiles, and antioxidant metabolism. To this end, plants were placed in a hydroponic system and grown in the presence of the following micronutrient combinations: $\mathrm{T} 1(0.041 \mathrm{mM} \mathrm{Cu}+0.085 \mathrm{mM} \mathrm{Zn}$ [control]); T2 (0.041 mM Cu+ $0.850 \mathrm{mM} \mathrm{Zn})$; T3 (0.123 $\mathrm{mM} \mathrm{Cu}+0.085 \mathrm{mM} \mathrm{Zn})$, and T4 $(0.123 \mathrm{mM} \mathrm{Cu}+0.850 \mathrm{mM} \mathrm{Zn})$. Plants cultivated under T2, T3, and T4 conditions exhibited lower morphological parameters, higher hydrogen peroxide content, and higher lipid peroxidation than that in the control. Increased $\mathrm{Zn}$ concentrations, regardless of the $\mathrm{Cu}$ concentration (T2 and T4), resulted in the decreased uptake and transportation of macronutrients in plants. Furthermore, increased $\mathrm{Zn}$ concentrations promoted competition, sequestration, and compartmentalization mechanisms of micronutrients in the roots, and activation of antioxidant enzyme activity.
\end{abstract}

Keywords: mineral nutrition, micronutrient, antoxidant metabolism

RESUMO - Interação cobre e zinco: respostas morfofisiológicas em plantas de batata-doce (Ipomoea batatas L.) O objetivo do estudo foi avaliar o efeito conjunto de cobre $(\mathrm{Cu})$ e zinco $(\mathrm{Zn})$ sobre batata-doce, segundo parâmetros morfológicos, perfil mineral e metabolismo antioxidante. Para tanto, as mesmas foram colocadas em sistema hidropônico e cultivadas em diferentes combinações de micronutrientes: T1 $(0,041 \mathrm{mM} \mathrm{Cu}+0,085 \mathrm{mM} \mathrm{Zn}$ [controle]); T2 (0,041 mM Cu + 0,850 mM Zn); T3 $(0,123 \mathrm{mM} \mathrm{Cu}+0,085 \mathrm{mM} \mathrm{Zn})$ e T4 $(0,123 \mathrm{mM} \mathrm{Cu}+0,850 \mathrm{mM} \mathrm{Zn})$. As plantas cultivadas em T2, T3 e T4 apresentaram redução dos parâmetros morfológicos, aumento do conteúdo de $\mathrm{H}_{2} \mathrm{O}_{2}$ e da peroxidação lipídica quando comparadas ao controle. $\mathrm{O}$ aumento de $\mathrm{Zn}$ independente da concentração de $\mathrm{Cu}$ (T2 e T4) causou diminuição na absorção e transporte de macronutrientes na planta; promoveu mecanismos de competição, sequestro e compartimentalização de micronutrientes nas raízes e ativou a atividade das enzimas antioxidantes.

Palavras-chave: nutrição mineral, micronutriente, metabolismo antioxidante

\section{INTRODUCTION}

Both copper $(\mathrm{Cu})$ and zinc $(\mathrm{Zn})$ are naturally present in the environment at low concentrations, and the elements are micronutrients for plants (Giampaoli et al. 2012). Nevertheless, $\mathrm{Cu}$ and $\mathrm{Zn}$ also enter the environment via agricultural and industrial activities, and they may be toxic to plants at high concentrations (Nagajyoti et al. 2010; Giampaoli et al. 2012). Some species can tolerate excess heavy metals by adopting strategies of compartmentalization, quelation with metallothionein, or exclusion (Broadley et al. 2007). However, both $\mathrm{Cu}$ and $\mathrm{Zn}$ can accumulate in plant tissues, causing physiological and biochemical changes, growth reduction, and yield loss (Giampaoli et al. 2012).

The $\mathrm{Cu}$ ion is known to induced metabolic alterations in plant cells by bonding to the sulfhydryl groups associated with membrane proteins or enzymes, and this bonding affects the rate of lipid peroxidation, the uptake of other essential elements, chlorophyll synthesis, and electron transport (e.g., toxic effect on the primary photosynthetic reaction). Furthermore, this bonding mainly affects the formation of free radicals and reactive oxygen species
(ROS) through Haber-Weiss and Fenton reactions, because $\mathrm{Cu}$ is a redox-active transition metal (Posmyk et al. 2009).

Plants affected by high $\mathrm{Zn}$ concentrations can present symptoms similar to toxicity symptoms associated with other heavy metals such as cadmium or lead (Sagardoy et al. 2009). In most cases, excess $\mathrm{Zn}$ causes growth inhibition and root morphology alterations, biomass reduction, ROS generation and chlorosis induction in young leaves, decreased water content in tissues, and alterations in the uptake, translocation, and utilization of other essential elements (e.g., phosphorus, iron (Fe), or magnesium (Mg); Shi \& Cai 2009, Yang et al. 2011).

The distinct effects of $\mathrm{Cu}$ and $\mathrm{Zn}$ on plant metabolism have been widely studied, but little is known about the joint effects of these elements on physiological processes (Upadhyay \& Panda 2010). Both elements occur simultaneously in contaminated soils and in irrigation water, and the interaction between the two can result in additive or synergic harmful effects (Kasim 2005). This information is of fundamental importance to breeding programs that seek to develop tolerant genotypes that are capable of producing high yields under stressful conditions (Silva et al. 2010). Therefore, the objective of this study was to evaluate the 
joint effects of $\mathrm{Cu}$ and $\mathrm{Zn}$ on the development of the sweet potato (Ipomoea batatas L.), which is a model plant that is utilized in plant nutrition and metabolism studies (Adamski et al. 2011, 2012).

\section{MATERIAL AND METHODS}

In order to carry out the experiments, sweet potato apical branches (approximately $8 \mathrm{~cm}$ long with four leaves per branch) were obtained from plants established in a greenhouse, and the branches were subsequently rooted in water for five days. Afterwards, branches containing a root system (approximately $5 \mathrm{~cm}$ long) were transferred to a hydroponic system, and were kept for six days in a continuous flow solution culture. Plants were then cultivated in full Hoagland \& Arnon (1938) nutrient culture with 0.041 $\mathrm{mM}$ of $\mathrm{Cu}$ and $0.085 \mathrm{mM}$ of $\mathrm{Zn}$. Plants were cultivated for nine days before being cultivated in nutrient solutions containing different combinations of $\mathrm{Cu}(0.041$ and 0.123 $\mathrm{mM})$ and $\mathrm{Zn}(0.085$ and $0.850 \mathrm{mM})$ in the form of copper sulfate $\left(\mathrm{CuSO}_{4} \cdot 5 \mathrm{H}_{2} \mathrm{O}\right)$ and zinc sulfate $\left(\mathrm{ZnSO}_{4} \cdot 7 \mathrm{H}_{2} \mathrm{O}\right)$, respectively. Therefore, the following four treatments were used: T1 $(0.041 \mathrm{mM} \mathrm{Cu}+0.085 \mathrm{mM} \mathrm{Zn}) ; \mathrm{T} 2(0.041$ $\mathrm{mM} \mathrm{Cu}+0.850 \mathrm{mM} \mathrm{Zn}) ; \mathrm{T} 3(0.123 \mathrm{mM} \mathrm{Cu}+0.085$ $\mathrm{mM} \mathrm{Zn})$; and T4 $(0.123 \mathrm{mM} \mathrm{Cu}+0.850 \mathrm{mM} \mathrm{Zn})$. The treatments were determined after the evaluation of growth parameters based on previous assays, and the treatment with the lowest micronutrient concentration (T1) was the designated control. The solutions were renewed every three days, and the $\mathrm{pH}$ of each solution was adjusted to about 5.8. At the end of the experimental period, the plants were collected and evaluated with regard to growth, mineral profile, and antioxidant metabolism.

The following growth parameters were evaluated: branch length $(\mathrm{cm})$; number of leaves, fresh weight of the shoot and root (mg), dry weight (DW) of the shoot and root system $(\mathrm{mg})$, and leaf area $\left(\mathrm{cm}^{2}\right.$ plant $\left.{ }^{-1}\right)$. Branch length and leaf number were based on increases during the experimental period. Branch length was evaluated with the aid of a metric ruler, and the leaf area was estimated using a leaf area meter (model LI-3100, LI-COR Inc., Lincoln, NE, USA). The dry weight of shoots and roots was measured with an analytical scale after drying the material in a forced ventilation oven at $70{ }^{\circ} \mathrm{C} \pm 2{ }^{\circ} \mathrm{C}$ until a constant weight (mg) was achieved.

The concentrations of macronutrients (nitrogen $(\mathrm{N})$, potassium $(\mathrm{K})$, calcium $(\mathrm{Ca})$, and $\mathrm{Mg}$ ) and micronutrients $(\mathrm{Cu}, \mathrm{Zn}, \mathrm{Fe}$, and manganese [Mn]) were determined based on the DW of leaves and roots according to the method reported by Tedesco et al. (1995). In order to observe the effects of different $\mathrm{Cu}$ and $\mathrm{Zn}$ concentrations, the nutrient levels were evaluated on completely expanded leaves that were established before the treatment application (referred to as "old leaves"), leaves that developed after the treatment application (referred to as "young leaves"), and roots.

To determine the activity of antioxidant enzymes, approximately $200 \mathrm{mg}$ of fresh matter (FM) from leaves and roots were ground in $\mathrm{N}_{2}$, added to $20 \%$ polyvinylpyrrolidone (PVPP), and homogenized with $1.8 \mathrm{~mL}$ of extraction medium (100 mM potassium phosphate buffer ( $\mathrm{pH} 7.8)$, $0.1 \mathrm{mM}$ EDTA, and $20 \mathrm{mM}$ ascorbic acid). The homogenate was centrifuged at $13,000 \mathrm{~g}$ for 20 minutes $\left(4^{\circ} \mathrm{C}\right)$, and the supernatant was collected to determine enzymatic activity and to quantify proteins using the Bradford method (1976).

Superoxide dismutase activity (SOD, EC 1.15.1.1) was determined based on the ability of SOD to inhibit the photoreduction of nitroblue tetrazolium (NBT) (Giannopolitis \& Ries 1977) in the reaction medium (100 $\mathrm{mM}$ potassium phosphate ( $\mathrm{pH} 7.8$ ), $14 \mathrm{mM}$ methionine, 0.1 $\mu \mathrm{M}$ EDTA, $75 \mu \mathrm{M}$ NBT, and $2 \mu \mathrm{M}$ riboflavin). One unit of SOD was considered the amount of enzyme required to inhibit 50\% NBT photoreduction under test conditions. The results were expressed as $\mathrm{U} \mathrm{mg}^{-1}$ protein.

Ascorbate peroxidase activity (APX, EC 1.11.1.11) was evaluated according to the method described by Nakano \& Asada (1981), which monitored the oxidation rate of ascorbate (ASA) at $290 \mathrm{~nm}$. The incubation buffer was composed of $100 \mathrm{mM}$ potassium phosphate ( $\mathrm{pH} 7.0$ ), 0.5 $\mathrm{mM}$ ascorbic acid, $0.1 \mathrm{mM}$ hydrogen peroxide $\left(\mathrm{H}_{2} \mathrm{O}_{2}\right)$, and enzyme extract. The decrease in absorbance was monitored over a 1.5-minute period, and the results were expressed as $\mu \mathrm{mol} \mathrm{ASA} \mathrm{min}^{-1} \mathrm{mg}^{-1}$ protein.

Catalase activity (CAT, EC 1.11.1.6) was determined as described by Azevedo et al. (1998). The enzyme extract was added to the reaction medium $(50 \mathrm{mM}$ potassium phosphate ( $\mathrm{pH} 7.0$ ) and $12.5 \mathrm{mM} \mathrm{H}_{2} \mathrm{O}_{2}$ ), and the activity was indicated by decreased absorbance at $240 \mathrm{~nm}$ over a 1.5 -minute period. The results were expressed as $\mu \mathrm{mol}$ $\mathrm{H}_{2} \mathrm{O}_{2} \mathrm{~min}^{-1} \mathrm{mg}^{-1}$ protein.

$\mathrm{H}_{2} \mathrm{O}_{2}$ content and lipid peroxidation were determined using approximately $300 \mathrm{mg}$ of fresh matter (FM) from leaves and roots. The tissues were ground in $\mathrm{N}_{2}$ and added to $2 \mathrm{~mL}$ of the extraction solution containing 20\% PVPP and $0.1 \%$ trichloroacetic acid (TCA). The homogenate was centrifuged at $12,000 \mathrm{~g}$ for 20 minutes, and the supernatant was separated for the next analysis.

Lipid peroxidation was determined based on the quantification of species reactive to thiobarbituric acid (TBA), as described by Cakmak \& Horst (1991). TBA forms reddish-colored complexes with low molecular mass aldehydes such as malondialdehyde (MDA), which is a secondary product of the peroxidation process. The concentration of the MDA/TBA complex was calculated using the following equation: $[\mathrm{MDA}]=(\mathrm{A} 535-\mathrm{A} 600) /$ $(\xi \times \mathrm{b})$, where $\xi$ : extinction coefficient $=1.56 \times 10^{-5} \mathrm{~cm}^{-1}$; b: optical length $=1$. Peroxidation was expressed as $\mu \mathrm{mol}$ $\mathrm{mg}^{-1} \mathrm{FM}$.

$\mathrm{H}_{2} \mathrm{O}_{2}$ quantification was determined according to Velikova et al. (2000). The enzymatic extract was added to the quantification medium $(10 \mathrm{mM}$ potassium phosphate buffer $(\mathrm{pH} \mathrm{7.0)}$ and $1 \mathrm{M} \mathrm{KI})$ followed by incubation for 10 minutes at $30{ }^{\circ} \mathrm{C}$. The readings were conducted in a spectrophotometer at $390 \mathrm{~nm}$, and the $\mathrm{H}_{2} \mathrm{O}_{2}$ concentration was expressed as $\mu \mathrm{mol} \mathrm{g}^{-1} \mathrm{FM}$. 
The experiments were conducted in a completely randomized design composed of four treatments (T1, T2, T3, and T4) and five replications. Each replication consisted of a pot containing five plants. The results were subjected to an analysis of variance (ANOVA), and the means were compared using Tukey's test $(\mathrm{p} \leq 0.05)$ (Machado \& Conceição 2007).

\section{RESULTS AND DISCUSSION}

The main effect of toxicity associated with heavy metals is the reduction or inhibition of growth (Posmyk et al. 2009). Plants cultivated in different combinations of $\mathrm{Cu}$ and $\mathrm{Zn}$ exhibited marked reductions of all morphological parameters compared to the control (T1; Fig. 1). The shoot length $(p=0.00008)$, leaf area $(p=0.005)$, shoot-fresh weight $(p=0.0007)$, root-fresh weight $(p=0.0006)$, and root-dry weight $(p=0.0005)$ values of plants cultivated under T2, T3, and T4 conditions were lower by $23,13,13$, 30 , and $24 \%$, respectively, than the control values (T1; Fig. 1). Furthermore, the results of the three treatments (T2, T3, and T4) also indicated decreased leaf numbers. Plants cultivated under $\mathrm{T} 3$ conditions reached $25 \%$ of the values exhibited under T1 conditions, while plants cultivated under T2 and T4 conditions exhibited statistically similar results and produced $40 \%$ of the number of leaves produced under T1 conditions $(p=0.0004)$. Nevertheless, significant reductions in shoot-dry weight $(p=0.0005)$ were observed as the availability of micronutrients increased, and plants cultivated under T2, T3, and T4 conditions exhibited 30 , 19 , and $17 \%$, respectively, of the values measured in the control treatment (T1).

The observed responses could have resulted from the inhibition of cell division or to additive effects of micronutrients under the studied growth conditions (Kasim 2005, Upadhyay \& Panda 2010). According to Fageria (2001), when the combination of nutrients results in growth responses smaller than the control, the interaction is negative. Based on that conclusion, one can infer that the $\mathrm{Cu}-\mathrm{Zn}$ relationships examined in this work were antagonistic.

According to Kabata-Pendias \& Pendias (2001), antagonistic interactions are competitive. Namely, the uptake of one element is inhibited by the other, and this suggests that they possess the same carriers during the cell uptake process, which regulate homeostasis under varying environmental conditions. Consequently, several families of heavy metal carriers involved in the intracellular balance of $\mathrm{Cu}$ and $\mathrm{Zn}$ have been discovered (Yruela 2009). The results determined based on the mineral profiles of root tissues and the results of Upadhyay \& Panda (2010) confirm this statement. Under the conditions of the present study, $\mathrm{Cu}$ inhibited the trapping of $\mathrm{Zn}$, and $\mathrm{Zn}$ in turn interfered with the $\mathrm{Cu}$ uptake process in a positive way (Figs. 2E, $2 \mathrm{~F}$ ). In addition to the uptake process, the inhibitory effects of $\mathrm{Zn}$ on the translocation of $\mathrm{Cu}$ in leaves (old and young) grown at low $\mathrm{Cu}$ concentrations ( $\mathrm{T} 1$ and $\mathrm{T} 2$ ) were found. However, the content of the studied elements was higher in the roots of sweet potato plants, and this result suggested that these organs developed sequestration and compartmentalization mechanisms (mainly for $\mathrm{Cu}$ ) as the availability of micronutrients increased, thus improving tolerance to heavy metals (Mateos-Naranjo et al. 2008).

In addition to these typical toxicity effects, sweet potato plants exhibited a marked decrease in $\mathrm{Mg}$ content in all parts of the plant (Fig. 2D), especially in treatments with high Zn concentrations (T2 and T4). According to Sagardoy et al. (2009), excessive $\mathrm{Zn}$ can induce $\mathrm{Mg}$ and $\mathrm{Fe}$ deficiencies, because the three metals possess similar ionic radii. Contrary to observations made by other researchers, Fe was compartmentalized, and the magnitude of Fe accumulation in the roots was greater under $\mathrm{T} 2$ and $\mathrm{T} 4$ conditions (Fig. $2 \mathrm{G})$. However, according data describing mineral profiles in leaves, Fe was translocated to the photosynthetic tissues and utilized along with $\mathrm{N}$ (content did not differ between the treatments in the organs studied) for chlorophyll synthesis (indicated by increasing chlorophyll content; data not shown), and it was supplied to other cell compartments that participated in various metabolic functions (Fig. 2A).

Environmental stresses, both biotic and abiotic, promote the increased production of ROS such as $\mathrm{H}_{2} \mathrm{O}_{2}$, superoxide anion $\left(\mathrm{O}_{2}^{-*}\right)$, and hydroxyl radical $\left({ }^{\circ} \mathrm{OH}\right)$ and the resulting accumulation in plants (Upadhyay \& Panda 2010). ROS are considered toxic compounds that can lead to damaged biological molecules (e.g., DNA, RNA, and proteins) and cell membranes (e.g., lipid peroxidation) (Shi-Sheng 2007). To repair the damage brought about by these molecules, plants have developed an antioxidant enzyme system, which includes the joint activity of SOD, CAT, and APX (Upadhyay \& Panda 2010).

SOD, the first line of antioxidant defense, sequesters $\mathrm{O}_{2}^{-}$ generated by the electron transport chain in chloroplasts and mitochondria, and the $\mathrm{H}_{2} \mathrm{O}_{2}$ produced by SOD activity is then eliminated by APX in different cellular compartments (Silva et al. 2010). CAT, the second enzyme to act in $\mathrm{H}_{2} \mathrm{O}_{2}$ removal when $\mathrm{H}_{2} \mathrm{O}_{2}$ concentrations are higher in the cell, is also responsible for removing $\mathrm{H}_{2} \mathrm{O}_{2}$ generated in the photorespiratory pathway inside peroxisomes (Mittler 2002).

MDA, the best measure of damages caused by ROS production, is a product of the decomposition of the polyunsaturated fatty acids of biomembranes, and it is indicative of plants exposed to high oxidative stress levels (Hou et al. 2007). In the present study, oxidative stress has been clearly established in sweet potato leaves and roots grown in high micronutrient concentrations, and this was indicated by the activity of antioxidant enzymes and increased $\mathrm{H}_{2} \mathrm{O}_{2}$ content and lipid peroxidation (Fig. 3).

In the leaves, the evaluation of SOD activity indicated significant differences between the treatments $(\mathrm{p}=$ 0.0005), its activity increased with combinations of lower and higher $\mathrm{Cu}$ concentrations and higher and lower $\mathrm{Zn}$ concentrations (T2 and T3). Moreover, SOD activity increased to approximately four times that observed under 

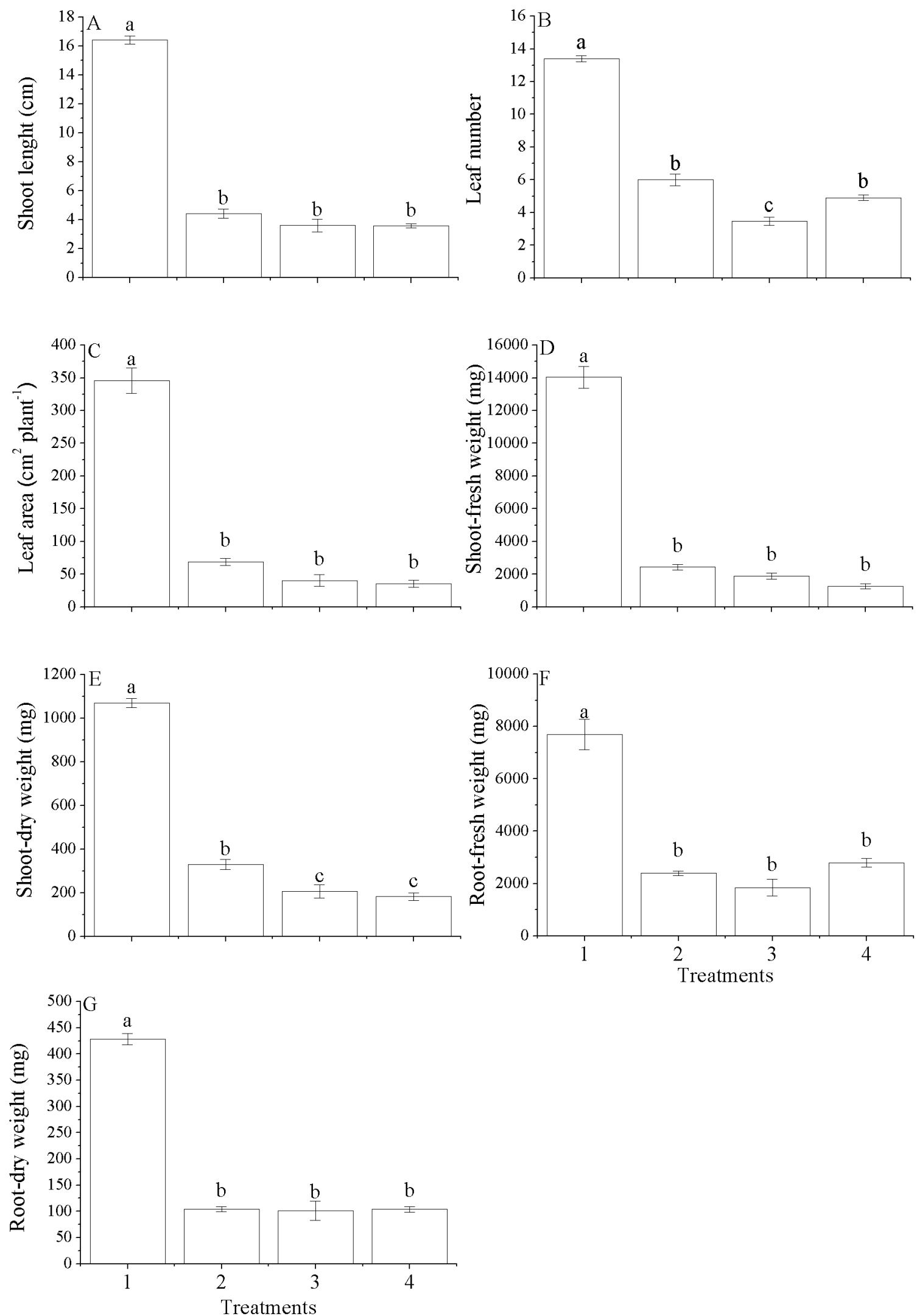

Figs. 1 A-G. Effects treatments with $\mathrm{Cu}$ and $\mathrm{Zn}$ concentrations on morphological parameters of sweet potato plants (Ipomoea batatas L.). A. Shoot length (cm); B. Leaf number; C. Leaf area $\left(\mathrm{cm}^{2}\right.$ plant $\left.^{-1}\right)$; D. Shoot-fresh weight (mg); E. Shoot-dry weight (mg); F. Root-fresh weight (mg); G. Root-dry weight (mg). Means followed by the same letter among treatments do not differ significantly according to Tukey's test ( $<<0.05$ ). 

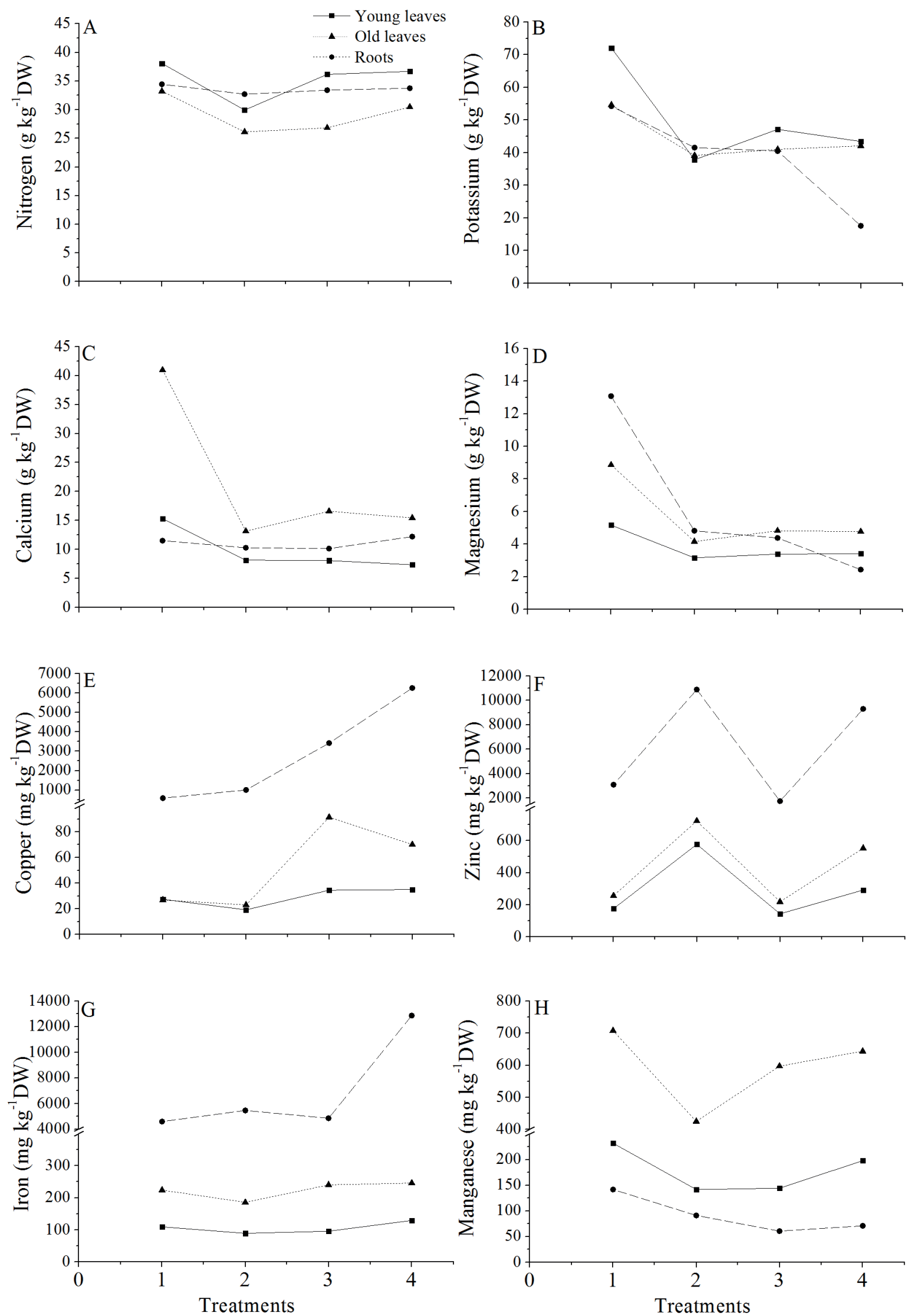

Figs. 2 A-H. Effects of $\mathrm{Cu}$ and $\mathrm{Zn}$ on the nutrient content, based on dry weight (DW), in sweet potato plants (Ipomoea batatas L.). A. Nitrogen (g $\left.\mathrm{kg}^{-1} \mathrm{DW}\right)$; B. Potassium (g kg-1 DW); C. Calcium ( $\left.\mathrm{g} \mathrm{kg}^{-1} \mathrm{DW}\right)$; D. Magnesium ( $\left.\mathrm{g} \mathrm{kg}^{-1} \mathrm{DW}\right)$; E. Copper $\left(\mathrm{mg} \mathrm{kg}^{-1} \mathrm{DW}\right) ; \mathbf{F}$. Zinc (mg kg-1 DW); G. Iron (mg kg-1 DW); H. Manganese ( $\left.\mathrm{mg} \mathrm{kg}^{-1} \mathrm{DW}\right)$. 
T1 conditions. T4 treatment resulted in values statistically similar to those of control plants (Fig. 3A). Regarding APX activity, there were no significant differences among treatments $(\mathrm{p}>0.05)$ (Fig. 3B). CAT activity indicated statistical differences only between $\mathrm{T} 2$ and $\mathrm{T} 3$ treatments $(\mathrm{p}=0.03)$. CAT enzyme activity in the treatment containing $0.041 \mathrm{mM}$ of $\mathrm{Cu}$ combined with $0.850 \mathrm{mM}$ of $\mathrm{Zn}$ (T2) was $57 \%$ higher than that of the control plants. On the other hand, the increased $\mathrm{Cu}$ concentration and decreased Zn concentration (T3) led to decreased CAT activity that was 30\% lower than that observed under T1 conditions. However, T4 did not differ from the treatment with lower micronutrient concentrations (Fig. 3C).

The evaluation of $\mathrm{H}_{2} \mathrm{O}_{2}$ content in the leaves indicated a significant difference between the treatments $(p=0.003)$. For instance, treatments 2,3 , and 4 had values 38,55 and $52 \%$ higher than those observed in the control plants, respectively (Fig. 3E). Similar responses were observed when determining the degree of lipid peroxidation (based on MDA formation), and values approximately two times higher than those found in the control treatment were detected. However, plants subjected to T3 conditions were not statistically different from the others (Fig. 3D).

In the root tissues, SOD activity (Fig. 3A) was 10 times higher with increasing $\mathrm{Zn}$ concentrations in the $\mathrm{T} 2$ treatment than in the control plants. However, in the T3 and $\mathrm{T} 4$ treatments, the activity did not differ significantly from $\mathrm{T} 1(\mathrm{p}=0.002)$. APX activity (Fig. 3B) in plants cultivated under T2, T3, and T4 conditions indicated increases of eight, five, and seven times relative to the control $(\mathrm{p}=$ 0.01 ), respectively. However, plants grown under T3 conditions did not differ statistically from the control. CAT activity increased dramatically with increasing $\mathrm{Zn}$ concentrations and maintenance of the $\mathrm{Cu}$ level (T2; $\mathrm{p}=$ 0.04 ), but treatments 3 and 4 did not differ significantly from the others (Fig. 3C).

The survey of the degree of lipid peroxidation in the roots (Fig. 3D) indicated a statistical difference only between $\mathrm{T} 2$ and $\mathrm{T} 3(\mathrm{p}=0.02)$ treatments. MDA values detected in the T2 plants were 2.3 times higher than those of the control plants. These values differed from those detected in the $\mathrm{T} 3$ treatments, which exhibited activity levels $40 \%$ lower than those of the control. However, T4 did not differ significantly from the treatment with lower micronutrient concentrations (T1). The results obtained with regard to the quantification of free $\mathrm{H}_{2} \mathrm{O}_{2}$ in the root tissue cells indicated significant differences among the treatments $(p=0.0003)$, and increased $\mathrm{H}_{2} \mathrm{O}_{2}$ levels were associated with increased micronutrient concentrations (Fig. 3E). $\mathrm{H}_{2} \mathrm{O}_{2}$ levels in plants grown under T2, T3, and T4 conditions were 8,18 , and $30 \%$ higher than those of control plants, respectively.

Based on the results associated with leaf tissues, it is possible to verify that SOD and CAT activities were stimulated by the additive effects of $0.850 \mathrm{mM}$ of $\mathrm{Zn}$ (T2). However, the activity was not sufficient based on the high levels of MDA and $\mathrm{H}_{2} \mathrm{O}_{2}$ found in these tissues
(Figs. 3D, 3E). The stimulus can result from decreased macronutrient and micronutrient (e.g., $\mathrm{K}, \mathrm{Ca}, \mathrm{Mg}, \mathrm{Cu}$, $\mathrm{Fe}$, and $\mathrm{Mn}$ ) content in those organs (Fig. 2), which could preclude the adequate functioning of plant metabolism and the generation of oxidative stress. The same was observed in leaves cultivated with $0.123 \mathrm{mM}$ of $\mathrm{Cu}$ and the same $\mathrm{Zn}$ level present in the control (T3), with the exception of the uptake and translocation of nutrients that were stimulated by increased $\mathrm{Cu}$ concentrations. However, in T4, the inhibition of SOD activity by the additive effect of $\mathrm{Cu}$ could be a consequence of poor gene expression or the degradation, denaturation, and/or inhibition or inactivation of those proteins (Cavalcanti et al. 2007). Another hypothesis is that the activity of this enzyme could have been reduced by both the compartmentalization and sequestration of micronutrients (e.g., $\mathrm{Zn}, \mathrm{Cu}$, and $\mathrm{Fe}$ ) in the root tissues, thus promoting reduced translocation to shoots and decreased ROS formation (Mateos-Naranjo et al. 2008).

The reduction of SOD activity (Fig. 3A), accompanied by increased CAT activity (Fig. 3C) and $\mathrm{H}_{2} \mathrm{O}_{2}$ content (Fig. $3 \mathrm{E})$ in the treatment with high $\mathrm{Cu}$ and $\mathrm{Zn}$ concentrations (T4), suggests the occurrence of photorespiration in leaves. Photorespiration is an alternative sink that aids in the consumption of power generated by the chloroplastid electron transport chain in $\mathrm{C}_{3}$ plants, which was likely stimulated by the stressful conditions (Wingler et al. 1999).

In the leaves, the intensity of lipid peroxidation was greater in plants subjected to the treatments with greater $\mathrm{Zn}$ concentrations (T2 and T4), thus suggesting the development of great oxidative damages independent of the utilized $\mathrm{Cu}$ concentration (Fig. 3D). These results, which differ from those found by Upadhyay \& Panda (2010), could be associated with the large amounts of $\mathrm{Zn}$ transported from the roots toward the leaves in those treatments. The authors showed the positive effects of $\mathrm{Zn}$ (e.g., reduced MDA levels and lipid peroxidation), thus indicating that $\mathrm{Zn}$ exists in a monovalent stable state in a biological environment. Therefore, the results suggest that the lipid membrane layer is protected by ROS.

Increased accumulation of micronutrients was found in the roots (Fig. 2), so the three enzymes were mainly stimulated by increased $\mathrm{Zn}$ concentrations (T2; Fig. 3). According to Silva et al. (2010), the maintenance of a favorable balance among SOD, APX, and CAT is essential for the avoidance of ROS accumulation and protection against oxidative damage (Guo et al. 2007). Nevertheless, the actions of those enzymes in plants grown under T2 conditions were insufficient, thus inducing increased MDA formation (Fig. 3D). The responses observed in the T3 treatment did not differ from those of the control, and there was only $\mathrm{H}_{2} \mathrm{O}_{2}$ accumulation in those tissues. The accumulation of ROS could act as a signal for greater stimulation of the antioxidant system (Giampaoli et al. 2012). Nevertheless, high micronutrient concentrations (T4) could be considered toxic to sweet potato plants, because they triggered APX and CAT activity in addition to oxidative damages. The decreased SOD activity under these 

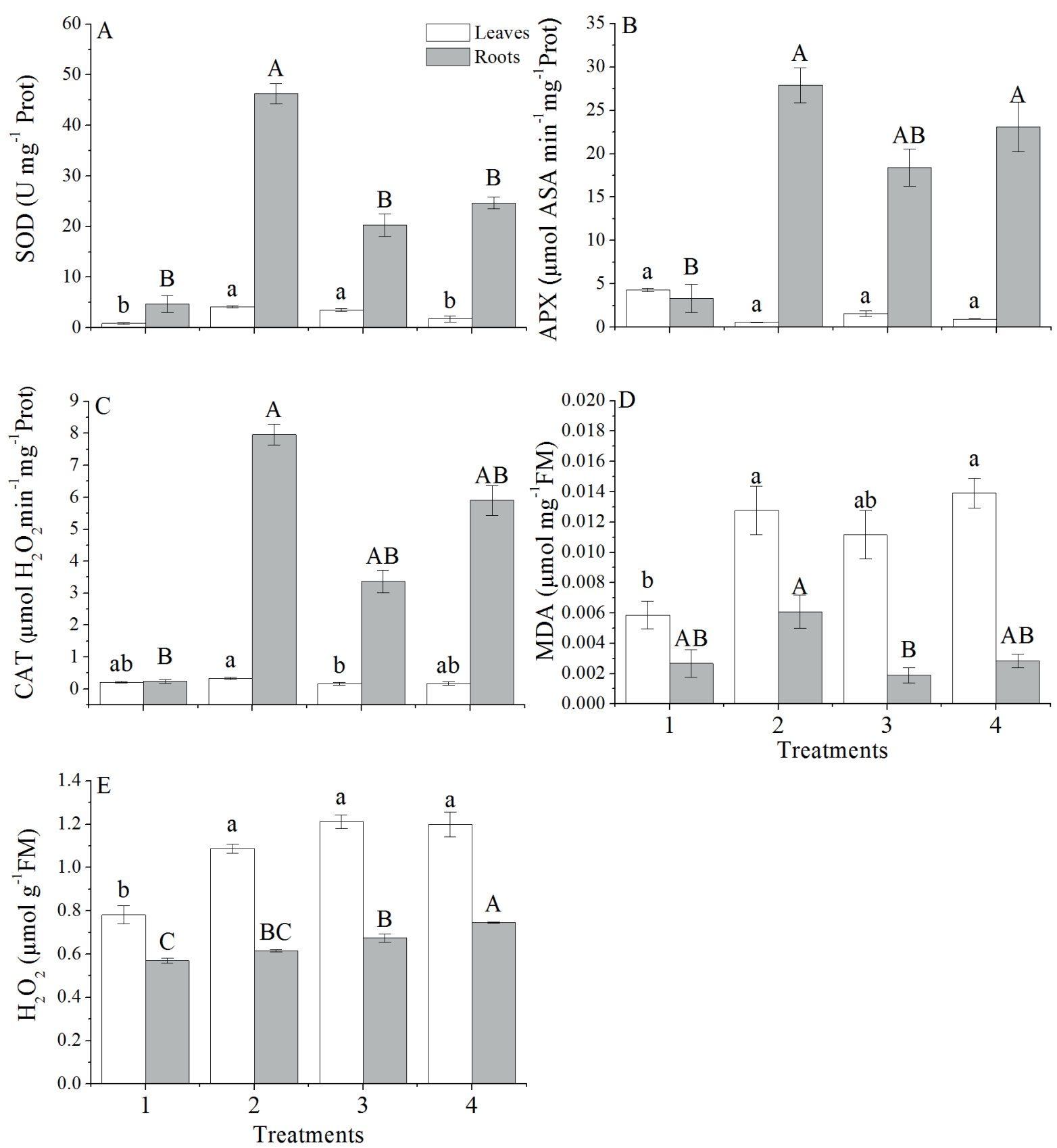

Figs. 3 A-E. Effects of treatments with different $\mathrm{Cu}$ and $\mathrm{Zn}$ concentrations on antioxidant metabolism in sweet potato plants (Ipomoea batatas L.). A. Superoxide dismutase (SOD); B. Ascorbate peroxidase (APX); C. Catalase (CAT); D. Lipid peroxidation (MDA); E. Hydrogen peroxide (H 2 ) content. Means followed by the same lowercase letters, associated with either leaf or root tissues, do not differ significantly from one another based on Tukey's test $(\mathrm{p}<0.05)$.

treatment conditions suggests that increased micronutrient availability could have inhibited the expression of enzymes involved in antioxidative metabolism at the molecular level (Posmyk et al. 2009). Therefore, other factors such as subcellular distribution could affect the enzymatic performance of plants exposed to heavy metals (Giampaoli et al. 2012).

In summary, increased $\mathrm{Zn}$, independent of the $\mathrm{Cu}$ concentration (T2 and T4), is toxic to sweet potato plants. Under these conditions, plants exhibited decreased uptake and transportation of macronutrients, promoted mechanisms of competition, sequestration, and compartmentalization of micronutrients in roots, and provoked oxidative stress and membrane damage.

\section{REFERENCES}

Adamski, J.M., Peters, J.A., Danieloski, R. \& Bacarin, M.A. 2011. Excess iron-induced changes in the photosynthetic characteristics of sweet potato. Journal of Plant Physiology 168(17): 2056-2062.

Adamski, J.M., Danieloski, R., Deuner, S., Braga, E.J.B., Castro, L.A.S. \& Peters, J.A. 2012. Responses to excess iron in sweet potato: impacts 
on growth, enzyme activities, mineral concentrations, and anatomy. Acta Physiologiae Plantarum 34(5): 1827-1836.

Azevedo, R.A., Alas, R.M., Smith, R.J. \& Lea, P.J. 1998. Response from elevated carbon dioxide to air and ozone fumigation in leaves and roots of wild type and a catalase-deficient mutant of barley. Physiologia Plantarum 104(2): 280-292.

Bradford, M.M. 1976. A rapid and sensitive method for the quantitation of microgram quantities of protein utilizing the principle of proteindye binding. Analytical Biochemistry 72(1-2): 48-254.

Broadley, M., White, P.J., Hammond, J.P., Zelko, I. \& Lux, A. 2007. Zinc in plants. New Phytologist 173(4): 677-702.

Cavalcanti, F.R., Lima, J.P.M.S., Ferreira-Silva, S.L., Viégas, R.A. \& Silveira, J.A.G. 2007. Roots and leaves display contrasting oxidative response during salt stress and recovery in cowpea. Journal of Plant Physiology 164(5): 591-600.

Cakmak, I. \& Horst, W.J. 1991. Effect of aluminium on lipid peroxidation, superoxide dismutase, catalase, and peroxidase activities in root tips of soybean (Glycine max). Physiologia Plantatum 83(3): 463-468.

Fageria, V.D. 2001. Nutrient interactions in crop plants. Journal of Plant Nutrition 24(8): 1269-1290.

Giannopolitis, C.N. \& Ries, S.K. 1977. Superoxide dismutases. I. Occurrence in higher plants. Plant Physiology 59(2): 309-314.

Giampaoli, P., Tresmondi, F., Lima, G.P.P., Kanashiro, S., Alves, E.S., Domingos, M. \& Tavares, A.R. 2012. Analysis of tolerance to copper and zinc in Aechmea blanchetiana grown in vitro. Biologia Plantarum 56(1): 83-88.

Guo, Z., Huang, E.M., Lu, E.S., Yaqing, E.Z. \& Zhong, E.Q. 2007. Differential response to paraquat induced oxidative stress in two rice cultivars on antioxidants and chlorophyll a fluorescence. Acta Physiologiae Plantarum 29(1): 39-46.

Hoagland, D.R. \& Arnon, D. 1938. The water-culture method for growing plants without soil. University of California. College of Agriculture, Berkeley. 39 p.

Hou, W., Chen, X., Song, G., Wang, Q. \& Chang, C.C. 2007. Effect of copper and cadmium on heavy metal polluted water body restoration by duckweed (Lemna minor). Plant Physiology and Biochemistry 45(1): 62-69.

Kabata-Pendias, A. \& Pendias, H. 2001. Trace elements in soils and plants. CRC Press, Flórida. 315 p.

Kasim, W.A. 2005. The correlation between physiological and structural alterations induced by copper and cadmium stress in broad beans (Vicia faba L.). Egyptian Journal of Biology 7(1): 20-32.

Machado, A.A. \& Conceição, A.R. 2007. WinStat - Sistema de Análise Estatística para Windows. Versão 1.0. Universidade Federal de Pelotas.

Mateos-Naranjo, E., Redondo-Gómez, S., Cambrollé, J. \& Figueroa, M.E. 2008. Growth and photosynthetic responses to copper stress of an invasive cordgrass, Spartina densiflora. Marine Environmental Research 66(4): 459-465.

Mittler, R. 2002. Oxidative stress, antioxidants and stress tolerance. Trends Plant Science 7(9): 405-410.

Nagajyoti, P.C., Lee, K.D. \& Sreekanth, T.V.M. 2010. Heavy metals, occurrence and toxicity for plants: a review. Environmental Chemistry Letters 8(3): 199-216.

Nakano, Y. \& Asada, K. 1981. Hydrogen peroxide is scavenged by ascorbate specific peroxidase in spinach chloroplasts. Plant Cell Physiology 22(5): 867-880.

Posmyk, M.M., Kontek, R. \& Janas, K.M. 2009. Antioxidant enzymes activity and phenolic compounds content in red cabbage seedlings exposed to copper stress. Ecotoxicology and Environmental Safety 72(2): 596-602.

Sagardoy, R., Morales, F., López-Millán, A-F., Abadía, A. \& Abadía, J. 2009. Effects of zinc toxicity on sugar beet (Beta vulgaris L.) plants grown in hydroponics. Plant Biology 11(3): 339-350.

Shi, G.R. \& Cai, Q.S. 2009. Photosynthetic and anatomic responses of peanut leaves to zinc stress. Biologia Plantarum 53(2): 391-394.

Shi-Sheng, K. 2007. Effects of Copper on the Photosynthesis and Oxidative Metabolism of Amaranthus tricolor Seedlings. Agricultural Sciences in China 6(10): 1182-1192.

Silva, E.N., Ferreira-Silva, S.L., Fontenele, A.V., Ribeiro, R.V., Viégas, R.A. \& Silveira, J.A.G. 2010. Photosynthetic changes and protective mechanisms against oxidative damage subjected to isolated and combined drought and heat stresses in Jatropha curcas plants. Journal of Plant Physiology 167(14): 1157-1164.

Tedesco, M.J., Gianello, C., Bissani, C.A., Bohnen, H. \& Volkweiss, S.J. 1995. Análise do solo, plantas e outros materiais. Universidade Federal do Rio Grande do Sul, Porto Alegre. 174 p.

Upadhyay, R. \& Panda, S.K. 2010. Zinc reduces copper toxicity induced oxidative stress by promoting antioxidant defense in freshly grown aquatic duckweed Spirodela polyrhiza L. Journal of Hazardous Materials 175(1-3): 1081-1084.

Velikova, V., Yordanov, I. \& Edreva, A. 2000. Oxidative stress and some antioxidant systems in acid rain-treated bean plants. Plant Science 151(1):59-66.

Wingler, A., Quick, W.P., Bungard, R.A., Bailey, K.J., Lea, P.J. \& Leegood, R.C. 1999. The role of photorespiration during drought stress: an analysis utilizing barley mutants with reduced activities of photorespiratory enzymes. Plant, Cell and Environment 22(4): 361-373.

Yang, Y., Sun, C., Yao, Y., Zhang, Y. \& Achal, V. 2011. Growth and physiological responses of grape (Vitis vinifera "Combier") to excess zinc. Acta Physiologiae Plantarum 33(4): 1483-1491.

Yruela, I. 2009. Copper in plants: acquisition, transport and interactions. Functional Plant Biology 36(5): 409-430. 